\title{
Clinical Management of Hemolytic Disease of the Newborn and Fetus
}

\author{
Sebastian Illanes and Rafael Jensen \\ Fetal Medicine Unit, University of Los Andes, Santiago
}

Chile

\section{Introduction}

Hemolytic disease of the fetus and newborn (HDFN) is caused by maternal alloantibodies directed against antigens present in fetal red cells. Paternally inherited antigens of the $\mathrm{Rh}$ system, which differ to those from the mother, are present on fetal red cells and when the maternal immune system makes contact with a significant number of these cells create an immune response with antibodies against these antigens. This may happen because of fetomaternal transplacental bleeding (in traumatic events during pregnancy, obstetric procedures, labor, cesarean section) or by events unrelated with pregnancy, such as transfusion, contamination by needle use, etc. Maternal antibodies (IgG) can cross the placenta and activate macrophages in the fetal spleen which cause fetal red cell destruction with subsequent hemolytic anemia. This leads to jaundice and kernicterus in the newborn or hydrops and death in the fetus.

Before the 70's, HDFN was a major obstetric problem, that had a large impact on fetal and neonatal morbidity and mortality. Today, without an appropriate programme, up to $50 \%$ of untreated HDFN will result in death or severe brain damage. In developing countries, especially those lacking an efficient prophylactics progamme, this causes an important public health problem. In fact, it has been estimated that more than 50 thousand fetuses could be affected by this condition every year in India (Zipursky and Paul, 2010). With the established use of post-natal anti-D prophylaxis for rhesus (Rh) negative women, together with its increasing use for routine antenatal prophylaxis, the incidence of Rh-D sensitization has dramatically fallen (Hughes RG et al., 1994). Nevertheless, $15-17 \%$ of the Caucasian population in Europe and North America is D negative (Ubarkian S, 2002). With the sensitization against other red cell antigens such as Kell RhC/c, RhE/e, this pathology could still affect a large number of pregnancies every year, with significant health and financial implications (Abdel-Fattah SA et al., 2002; Illanes S and Soothill P, 2009). In England and Wales, about 520 fetuses develop HDFN each year, of which about 37 would die in the fetal or neonatal period and 28 would present developmental problems (Daniels G et al., 2004, NICE 2008).

On the other hand, in fetus affected by HDFN, survival rates can exceed 90 percent if anemia is diagnosed and treated with intrauterine blood transfusions in a timely manner (Van Kamp IL et al., 2001). Women with rising red cell antibody levels are usually referred to tertiary fetal medicine units for specialized management. The main challenge facing fetal medicine 
specialists today is not the skill required for invasive therapy, but rather the non-invasive monitoring of the disease so that its progress can be predicted to guide the need and timing of intrauterine transfusions to minimize unnecessary invasive testing (Ubarkian S, 2002).

\section{Non-invasive management}

\subsection{Use of cell-free fetal DNA for the determination of fetal RhD genotype}

The identification of blood group genes and subsequent detection of the molecular bases of blood group polymorphisms has made it possible to predict blood group phenotypes (Avent ND et al., 2000). The source of DNA used to predict fetal blood groups was initially done invasively by sampling amniotic fluid or chorionic villi (Finning KM et al., 2002). However, the related risk of the obstetric procedures $(0.5-1 \%$ for fetal loss) (Nanal $\mathrm{R}$ et al., 2003) and risk of fetomaternal hemorrhage (amniocentesis 17\%) (Tabor A et al., 1987) was associated with an unwanted increase in gestational maternal immunization (Murray JC et al., 1983).

The fact that cell-free fetal DNA (ffDNA) is present in the plasma of pregnant women in sufficient quantities for the determination of fetal RhD genotype (Lo YM, 1999), leads to the possibility of fetal $\mathrm{D}$ typing using a non-invasive approach. If the rhesus sequence is present in a D-negative women's blood it is indicative that the fetus is D-positive (Lo YM et al., 1997). Initially, cell-free DNA was studied as a tumor marker (Lo YM et al., 1998), but the presence of $\mathrm{Y}$ signals in pregnant women carrying a male fetus was the first evidence that this technique could be used to assess the fetus condition as well as for prenatal diagnosis (Lo YM et al., 1997). In a normal pregnancy, the placental tissue goes through a physiological remodeling via apoptosis and necrosis in the chorionic villus. As a consequence, ffDNA is released to the maternal plasma in increasing amounts as gestation progresses (Wataganara T and Bianchi DW, 2004; Alberry MS et al., 2009; Huppertz B et al., 2006; Fomigli L et al., 2000; Arnholdt H et al., 1991; Illanes S et al., 2009).

Non-invasive prenatal diagnosis using ffDNA is the focus of intense research nowadays because of its many potential uses. It's being evaluated for inherited diseases and genetic disorders such as trisomy 21 (Ehrich M et al., 2011; Deng YH et al., 2011; Sehnert AJ et al, 2011), trisomy 18 (Sehnert AJ et al, 2011), $\beta$-thalassaemia (Li Y et al, 2009; Hahn S et al., 2011), hemophilia (Tsui NB et al., 2011), X-linked genetic disorders (Miura K et al., 2011) and achondroplasia (Chitty LS et al., 2011). Genome-wide scanning may be implemented for fetal genetic prenatal non-invasive diagnosis (Lo YM el al., 2010) and quantitative changes in ffDNA blood levels have been proposed as a potential marker for preeclampsia (Hahn $S$ et al., 2011). Finally, the combination of real-time PCR with improved rhesus D (RhD) typing enables a highly accurate prediction of fetal D status from maternal plasma (Finning KM et al., 2002). Moreover, this is now available as a world-wide service (Daniels G et al., 2004; Finning KM et al., 2002; Finning KM et al., 2004; Legler TJ et al., 2002; Rouillac-Le Sciellour C et al., 2004; Van der Schoot CE et al, 2006; Tynan JA et al., 2011; Tounta G et al., 2011)

A recent meta-analysis has been performed to evaluate the diagnostic sensitivity and specificity of fetal Rh genotyping using ffDNA (Geifman-Holtzman O et al., 2006). A total of 3261maternal plasma samples were analyzed in 37 publications and approximately 500 study protocols in order to assess fetal RhD status. Results showed total accuracy of $91.4 \%$ (94,8\% if studies with small numbers of samples were excluded), with a wide variation, from 31.8 to 100 percent, depending on which protocol, gestational age at testing and study 
design was applied. Two recent studies have evaluated the feasibility of this testing in the first trimester of pregnancy. Akolekar et al tested patients at 11-13 weeks using a highthroughput robotic technique. They concluded that it was an accurate method with a positive predictive value of $100 \%$ and a negative predictive value of 96,5\% (Akolekar $\mathrm{R}$ et al., 2011). The second study, reported a sensitivity of $100 \%$ and a specificity of $93 \%$, with a $97 \%$ diagnostic accuracy for $\mathrm{RhD}$ genotyping in the first trimester of pregnancy using a quantitave PCR method (Cardo el al., 2010)

Non-invasive fetal RhD genotyping was compared to traditional postnatal serologic assay in a large scale validation study (Müller SP et al., 2008). The authors studied over one thousand samples of RH negative women who gave whole blood specimens at a gestational age of 25 weeks. Tests were drawn up using an innovative automated DNA extraction method using magnetic tips and spin columns that have been recently developed by members of Special Non-Invasive Advances in Fetal and Neonatal Evaluation Network of Excellence (SAFE NoE) (Chitty LS et al., 2008; Legler TJ et al., 2007). The sensitivity of fetal RHD genotyping was $99.7 \%$ for spin columns and $99.8 \%$ for magnetic tips, and these results were comparable to conventional serology (99.5\%). In the case of specificity, the serology was slightly better $(99.7 \%$ versus $99.2 \%$ for spin columns and $98.1 \%$ for magnetic tips). It has also been established that it is an accurate method in multi-ethnic populations such as Brazil, by using two or three exons for RHD gene (Amaral DR et al, 2011; Chinen PA et al., 2010). This new approach has significantly reduced the number of invasive procedures carried out in different fetal medicine units for fetal D grouping (Finning KM et al., 2004) and has proved that the automated DNA extraction method can be used in a clinical setting.

Non-invasive studies for other blood group antigens have also been flourishing, including Kell antigen, the second most important cause of hemolytic disease (Li Y et al., 2008), RhC/c and RhE/e (Li Y et al., 2008; Van der Schoot CE et al., 2003; Finning K et al., 2007). The International Blood Group Reference Laboratory, at Bristol (Finning K et al., 2007) has developed and tested allele-specific primers for detecting the K allele of KEL and alleles of $\mathrm{RhC/c} \mathrm{RhE} / \mathrm{e}$ (Van der Schoot CE et al., 2003), with great accuracy for each allele. The matrix assisted laser desorption/ionization time-of-flight mass spectrometry or MALDITOF MS (Li Y et al., 2008), is able to detect the fetal KEL1 allele in KEL negative mothers with an accuracy of $94 \%$. In a recent meta-analysis, collective reported diagnostic accuracy of fetal RhCE genotyping, with a combined accuracy for fetal genotyping of $96.3 \%$ for $\mathrm{RhC} / \mathrm{c}$ and 98.2\% for RhE/e (Geifman-Holtzman O et al., 2009) was estimated. A recent Dutch report, after 7 years of non-invasive fetal blood group genotyping from maternal blood samples for $\mathrm{D}, \mathrm{K}, \mathrm{C}$, and $\mathrm{E}$ groups, revealed that diagnosis could be achieved in $97 \%$ of cases in a medium gestational age of 17 weeks, with no false-positive or false-negative results, implying that it is an accurate and applicable diagnostic tool in clinic (Scheffer P et al., 2011). The use of cell-free fetal DNA in maternal plasma for fetal RhD genotype could eventually enable the screening of all D negative pregnant women, thereby confining the administration of prophylactic anti-D only to those pregnancies in which it is needed (Bianchi DW et al., 2005). Since the accuracy of the actual test is not $100 \%$, there is an ongoing debate about the advantage of introducing such a policy. Some researchers propose that guided prophylaxis should have a lower cost than the routine prophylaxis to all $\mathrm{RhD}$ negative women (Daniels G et al., 2009). However, a recent cost benefits study evaluated the implementation of this strategy in England and Wales, and concluded that is unlikely to be sufficiently cost-effective for a large scale introduction. They estimated that only minor 
savings would be gained and that an increase in maternal sensitization may be unacceptably high due to test inaccuracies in different ethnic minority populations (Szczepura A et al., 2011). It is expected that new technologies should alter this picture. Nevertheless, any policy for the prevention of unnecessary administration of human-derived products, such as prophylactic anti-D, should be taken into account because of the potential contamination of blood products that at the present time cannot be tested, as unidentified viruses or prions (Avent ND. 2008, Avent ND. 2009).

\section{Detection of fetal anemia non-invasively by ultrasonography}

\subsection{Ultrasound findings}

Severe anemia causes tissue hypoxia (Soothill PW et al., 1987), with endothelial damage and increased capillary permeability. This may lead to protein loss into the interstitial space, hypoproteinaemia and consequently ascites (Nicolaides KH et al., 1985). Moreover, in response to red cell haemolysis and fetal anemia, extramedullary haematopoiesis occurs, increasing portal and umbilical venous pressures. This would impair hepatic function and protein synthesis, resulting in worsening hypoproteinaemia which would further deteriorate the hydrops process (Bowman JM, 1978; Socol ML et al., 1987). The ultrasonographic features of hydrops include ascites (the earliest sign), pleural effusions, pericardial effusions, scalp edema, subcutaneous edema and polyhydramnios. These findings are an indication of a hemoglobin deficit of more than 6 standard deviations below the normal mean for gestational age, and will need urgent intrauterine fetal transfusion (Nicolaides KH et al., 1988).

The many attempts to identify sonographic fetal anemia features which occur before the development of fetal hydrops have been unsuccessful (Queenan JT, 1982, De Vore GR et al., 1981,Nicolaides KH et al., 1988), because of their failure to quantify the real degree of the fetal anemia (Nicolaides KH et al., 1988). Moreover, these ultrasound findings, including the evaluation of the liver and spleen, have been abandoned, because when high quality Doppler measurements are used to predict fetal anemia, these anatomic evaluations add little useful independent information. In our practice, we don't usually look for any structural measurement or appearance, save for the early signs of fetal ascites.

\subsection{Fetal Doppler ultrasonography}

Doppler ultrasonography is a non-invasive method used for studying fetal hemodynamic changes in vessels that supply fetal organs responding to pathological conditions. In anemic fetuses, the Doppler measurement that describes the hemodynamic changes occurring in response to this pathological condition has been attempted in several vessels. However, because of the rapid hemodynamic changes observed in the middle cerebral artery (MCA) (Mari G et al., 2000), have transformed the measurement of its peak systolic velocity (the maximum Doppler shift at the peak of the spectral curve) in the gold standard for anemia fetal prediction. (Campbell S et al., 1995). After Vyas et al in 1990 (Vyas et al., 1990) described an increase in the average MCA time for mean blood velocity in fetal anemia cases, Mari and colleagues reported that the degree of fetal anemia could be accurately detected by Doppler measurement of blood-flow velocity in the MCA, with an inverse relationship between the MCA peak velocity and the fetal hematocrit, with no false negative results for anemic fetuses (Mari G et al., 2000). The statistically significant increase in fetal hematocrit, following intrauterine transfusion, also resulted in a rapid reduction in the 
middle cerebral artery peak velocity. These results confirm that the traditional management of pregnancies complicated by $\mathrm{Rh}$ alloimmunization with serial invasive amniocentesis to determine bilirubin levels is no longer required. Even more, a recent study has shown that Doppler measurement of the peak velocity of systolic blood flow in the MCA can safely replace invasive testing in the management of $\mathrm{Rh}$-alloimmunized pregnancies, avoiding all the complications related with the traditional invasive approach (Oepkes et al., 2006).

Several studies have used the MCA Dopplers in a clinical basis for the prediction of fetal anemia with at-risk cases, without ultrasound evidence of fetal hydrops. These have shown that there is a good correlation with fetal Hemoglobin (Abdel-Fattah SA et al., 2002). This non-invasive investigation can be reliable in predicting anemia in cases in which the need to sample fetal blood is not certain, therefore delaying invasive testing until treatment is likely to be required. The neonatal outcome where invasive testing has been avoided (based on reassuring MCA Doppler velocity results) did not result in life-threatening fetal or neonatal morbidities (Abdel-Fattah SA et al, 2005). Therefore, the routine use of MCA Doppler's can avoid unnecessary invasive procedures on at-risk fetuses. There are several normal reference ranges of fetal blood flow velocity in the middle cerebral artery. However, when compared in terms of discriminatory power, sensitivity and specificity, Mari's curve and its given cut-offs perform better when fetal anemia is predicted. (Mari G et al., 2000; Bartha JL et al., 2005).

\section{Invasive approach}

Intrauterine blood transfusion of anemic fetuses represents one of the great successes of fetal therapy. After the first approach with intraperitoneal blood transfusion introduced in 1963 by Liley (Liley AW, 1963), Rodeck (Rodeck $\mathrm{CH}$ et al., 1981) described intravascular fetal blood transfusion (IVT) by the needling of the chorionic plate or umbilical cord vessels via fetoscopy direct vision. In 1982, Bang in Denmark started IVT by umbilical cord puncture under ultrasound guidance. This is now the gold standart (Bang et al., 1982). IVT has produced a marked improvement in the survival rate of the anemic hydropic fetus. This in turn can also prevent complications from developing by treating anemic non-hydropic fetuses, where moderate or severe anemia is detected non-invasively by Doppler ultrasonography, by increased peak velocity of systolic blood flow or time-averaged mean velocity in the MCA in fetuses at risk (Abdel-Fattah SA et al., 2002; Mari G et al., 2000). It is estimated that between 10 and $12 \%$ of fetuses of sensitized RHD negative women will require IVT (NICE 2008) with the survival rate exceeding 95\% in experienced centers, particularly when opportune IVT treatment is established in a timely manner (Van Kamp IL et al., 2001).

When possible the umbilical vein is sampled because artery puncture may pose a risk for bradycardia (Weiner CP et al., 1991). The hemoglobin concentration $(\mathrm{Hb})$ is measured and interpreted according to gestational age, with the severity classified on the fetal hemoglobin deviation from the normal mean for gestation into mild (hemoglobin deficit less than 2 $\mathrm{g} / \mathrm{dl}$ ), moderate (deficit 2-7 g/dl), and severe (deficit greater than $7 \mathrm{~g} / \mathrm{dl}$ ) (Nicolaides $\mathrm{KH}$ et al., 1988). A blood transfusion will be attempted in cases were a moderate or severe anemia is detected. For IVT to be realized, the blood volume required to correct the fetal $\mathrm{Hb}$ needs to be calculated, using pre-transfusion fetal $\mathrm{Hb}$, the donor blood $\mathrm{Hb}$ (adult blood usually packed to a hematocrit of about 70-80\%) and the gestational age (Nicolaides KH et al., 1986). The volume required is given as fast as possible without causing changes to the fetal heart 
rate and it seems that the feto-placental unit is able to handle the blood volume expansion much more easily than when transfusing neonates without the benefit of a placenta. Infusion of packed blood through a $15-\mathrm{cm}$ long, 20-gauge needle at rates of $1-10 \mathrm{ml} / \mathrm{min}$ does not result in significant hemolysis (Nicolaides $\mathrm{KH}$ et al., 1986). After the volume calculated to correct the $\mathrm{Hb}$ deficit has been given a post-transfusion, $\mathrm{Hb}$ is measured to help time the subsequent transfusion. After two or three transfusions, fetal blood production is suppressed and instead adult blood cells become more dominant. The fall of $\mathrm{Hb}$ becomes very predictable at about $1 \%$ haematocrit point per day (Thein AT and Soothill $\mathrm{P}, 1998$ ). We aim to complete the last transfusion at 35-36 weeks and then to induce labor at 37 weeks to allow maturation of both the pulmonary and hepatic enzyme systems. With this programme, we hope to avoid neonatal exchange transfusions.

As this management of anemic fetuses is increasing, and the number of cordocentesis and transfusions are decreasing, the problem of maintaining the skills needed is rising too. It has been suggested that operators should perform at least 10 procedures per year to keep competence. (Lindenburg IT et al., 2011). Complications associated with intrauterine procedures such as cord hematoma, hemorrhage, fetal bradycardia and intrauterine death could increase in the future (Illanes $S$ and Soothill PW, 2006). A possible solution would be to introduce a health policy that gave transfusions, via some centers, to all those cases that needed one. This could potentially avoid any complications such as lack of operator training.

\section{Neonatal outcome}

For the neonate, the consequences of HDFN are anemia and hiperbilirrubinemia. Postnatal treatment options include top-up red blood cells transfusions for the former, and phototherapy and exchange transfusions for the latter. Top-up transfusions, even with a minimal risk, carry a theoretical possibility of anaphylactic reaction and transmission of viral disease. In contrast, exchange transfusion carries a high morbidity and mortality rate ( $5 \%$ and $<0.3 \%$ respectively), but the number of neonates requiring exchange transfusions has reduced due to advances in phototherapy.

Few studies specifically investigate the short-term neonatal outcomes for pregnancies affected by hemolytic red cell alloimmunisation. Two recent retrospective studies have assessed this question. De Boer et al. (De Boer et al 2008) investigated the short-term morbidity for neonates treated for Rhesus disease with or without IVT. Those treated with IVTs were found to require a higher number of top-up red blood cell transfusions and had less need of phototherapy. However, both groups had a similar need for exchange transfusion. The second study, is a Scottish report of postnatal outcomes following intrauterine transfusion, and showed that $20 \%$ of newborn needed exchange transfusion, $50 \%$ had top-up transfusion, and most of them needed phototherapy (McGlone L et al., 2009). More studies are needed, to evaluate the neonatal outcomes and associated morbi mortality, related to the number of transfusions, the gestational age at first and last transfusion, and the hemoglobin level at first IVT.

\section{Conclusion}

The management of the HDFN represents one of the genuine successes of fetal therapy. The current aspects of this clinical management have shifted from a long-established invasive 
approach to a non-invasive one. This applies to the detection of fetuses at risk of HDFN with the use of cell-free fetal DNA in the plasma of pregnant women to determine fetal RhD genotype. If the fetus is D negative, then it is not at risk and no further procedures are required; if it is D positive the appropriate management of the pregnancy can be arranged. On the other hand, maternal plasma testing for fetal RhD genotype could eventually enable the screening of all D negative pregnant women, thereby confining the administration of prophylactic anti-D only to those pregnancies in which it is needed. In addition, when a fetus is antigen positive, the follow up of these fetuses is for the detection of moderate or severe anemia non-invasively by Doppler ultrasonography on the basis of an increase in the peak velocity of systolic blood in the middle cerebral artery. When anemia is suspected, an invasive approach is required in order to perform an intrauterine blood transfusion which should only be attempted when the fetus needs transfusion.

\section{Summary}

Hemolytic disease of the fetus and newborn (HDFN) is caused by maternal alloantibodies directed against paternally inherited antigens on fetal red blood cells. It was also a significant cause of fetal and neonatal morbidity and mortality until the introduction of antiD immunoglobulin during pregnancy and shortly after delivery. However, it is still a major problem in affected pregnancies. The emphasis of current clinical management of HDFN is a non-invasive approach. This work is carried out on fetuses at risk with HDFN, with the use of cell-free fetal DNA in the plasma of pregnant women, in order to determine the fetal RhD genotype, or to see if the fetus is antigen positive. If the mother is sensitized, for the follow up and detection of moderate or severe anemia - this is done, primarily, non-invasively by Doppler ultrasonography of the middle cerebral artery. If anemia is suspected, an invasive approach is required in order to perform an intrauterine blood transfusion. This management represents one of the genuine successes of fetal therapy.

\section{References}

[1] Abdel-Fattah SA, Shefras J, Kyle PM, Cairns P, Hunter A, Soothill PW. Reassuring fetal middle cerebral artery doppler velocimetry in alloimmunised pregnancies: neonatal outcomes without invasive procedures. Fetal Diagn Ther. 2005 SepOct;20(5):341-5

[2] Abdel-Fattah SA, Soothill PW, Carroll SG, Kyle PM. Middle cerebral artery Doppler for the prediction of fetal anaemia in cases without hydrops: a practical approach. Br J Radiol. 2002 Sep;75(897):726-30

[3] Akolekar R, Finning K, Kuppusamy R, Daniels G, Nicolaides KH. Fetal RHD Genotyping in Maternal Plasma at 11-13 Weeks of Gestation. Fetal Diagn Ther. 2011;29(4):301-6. Epub 2011 Jan 8.

[4] Alberry MS, Maddocks DG, Hadi MA, Metawi H, Hunt LP, Abdel-Fattah SA, Avent ND, Soothill PW. 2009. Quantification of cell free fetal DNA in maternal plasma in normal pregnancies and in pregnancies with placental dysfunction. Am J Obstet Gynecol. 200(1):98.e1-6.

[5] Amaral DR, Credidio DC, Pellegrino J Jr, Castilho L. Fetal RHD genotyping by analysis of maternal plasma in a mixed population. J Clin Lab Anal. 2011;25(2):100-4. 
[6] Arnholdt H, Meisel F, Fandrey K, Lohrs U. 1991. Proliferation of villous trophoblast of the human placenta in normal and abnormal pregnancies. Virchows Arch B Cell Pathol Incl Mol Pathol.60: 365-72.

[7] Avent ND. 2008. RHD genotyping from maternal plasma: guidelines and technical challenges. Methods Mol Biol. 444:185-201.

[8] Avent ND. 2009. Large-scale blood group genotyping: clinical implications. $\mathrm{Br} \mathrm{J}$ Haematol. 144(1):3-13.

[9] Avent ND, Finning KM, Martin PG, Soothill PW. Prenatal determination of fetal blood group status. Vox Sang. 2000;78 Suppl 2:155-62.

[10] Bang J, Bock JE, Trolle D Ultrasound guided fetal intravenous transfusion for severe rehus haemolytic disease. BMJ 1982; 284: 373-374.

[11] Bartha JL, Illanes S, Abdel-Fattah S, Hunter A, Denbow M, Soothill PW. Comparison of different reference values of fetal blood flow velocity in the middle cerebral artery for predicting fetal anemia. Ultrasound Obstet Gynecol. 2005 Apr;25(4):335-40

[12] Bianchi DW, Avent ND, Costa JM, van der Schoot CE.Noninvasive prenatal diagnosis of fetal Rhesus D: ready for Prime(r) Time. Obstet Gynecol. 2005 Oct;106(4):841-4. Review.

[13] Bowman JM. The management of Rh isoimmunization. Obstet Gynecol 1978; 52: 1-16

[14] Campbell S, Harrington K, Hecher K. The fetal arterial circulation. In: A colour atlas of Doppler ultrasonography in obstetrics, Eds Harrington K, Campbell S. Edward Arnold 1995; 59-69

[15] Cardo L, García BP, Alvarez FV. Non-invasive fetal RHD genotyping in the first trimester of pregnancy. Clin Chem Lab Med. 2010 Aug;48(8):1121-6.

[16] Chinen PA, Nardozza LM, Martinhago CD, Camano L, Daher S, Pares DB, Minett T, Araujo Júnior E, Moron AF. Noninvasive determination of fetal rh blood group, D antigen status by cell-free DNA analysis in maternal plasma: experience in a Brazilian population. Am J Perinatol. 2010 Nov;27(10):759-62.

[17] Chitty LS, Griffin DR, Meaney C, Barrett A, Khalil A, Pajkrt E, Cole TJ. New aids for the non-invasive prenatal diagnosis of achondroplasia: dysmorphic features, charts of fetal size and molecular confirmation using cell-free fetal DNA in maternal plasma. Ultrasound Obstet Gynecol. 2011 Mar;37(3):283-9. doi: 10.1002/uog.8893. Epub 2011 Feb 1.

[18] Chitty LS, van der Schoot CE, Hahn S, Avent ND. 2008. SAFE-the Special Noninvasive Advances in Fetal and Neonatal Evaluation Network: aims and achievements. Prenat Diagn.28: 83-8.

[19] Daniels G, Finning K, Martin P, Massey E. 2009. Noninvasive prenatal diagnosis of fetal blood group phenotypes: current practice and future prospects. Prenat Diagn. 29(2): 101-7.

[20] Daniels G, Finning K, Martin P, Soothill P. Fetal blood group genotyping from DNA from maternal plasma: an important advance in the management and prevention of haemolytic disease of the fetus and newborn. Vox Sang. 2004 Nov;87(4):225-32. Review.

[21] De Boer, I.P., Zeestraten, E.C., Lopriore, E., van Kamp, I.L., Kanhai, H.H. \& Walther, F.J. Paediatric outcome in Rhesus haemolytic disease treated with and without intrauterine transfusion. American Journal of Obstetrics \& Gynaecology, 2008: 198(1):54.e1-4. 
[22] De Vore GR, Mayden K, Tortora M, Berkowitz RL, Hobbins JC. Dilation of the fetal umbilical vein in rhesus hemolytic anemia: a predictor of severe disease. Am J Obstet Gynecol 1981; 141: 464-66.

[23] Deng YH, Yin AH, He Q, Chen JC, He YS, Wang HQ, Li M, Chen HY. Non-invasive prenatal diagnosis of trisomy 21 by reverse transcriptase multiplex ligationdependent probe amplification. Clin Chem Lab Med. 2011 Apr;49(4):641-6.

[24] Ehrich M, Deciu C, Zwiefelhofer T, Tynan JA, Cagasan L, Tim R, Lu V, McCullough R, McCarthy E, Nygren AO, Dean J, Tang L, Hutchison D, Lu T, Wang H, Angkachatchai V, Oeth P, Cantor CR, Bombard A, van den Boom D. Noninvasive detection of fetal trisomy 21 by sequencing of DNA in maternal blood: a study in a clinical setting. Am J Obstet Gynecol. 2011 Mar;204(3):205.e1-11. Epub 2011 Feb 18.

[25] Finning K, Martin P, Daniels G. A clinical service in the UK to predict fetal Rh (Rhesus) D blood group using free fetal DNA in maternal plasma. Ann N Y Acad Sci. 2004.Jun;1022:119-23.

[26] Finning KM, Martin PG, Soothill PW and Avent ND, Prediction of fetal D status from maternal plasma: introduction of a new noninvasive fetal RHD genotyping service. Transfusion 42 (2002), pp. 1079-1085.

[27] Finning K, Martin P, Summers J, Daniels G. 2007. Fetal genotyping for the K (Kell) and $\mathrm{Rh}$ C, c, and E blood groups on cell-free fetal DNA in maternal plasma. Transfusion. 11: 2126-33.

[28] Formigli L, Papucci L, Tani A, et al. 2000. Aponecrosis: morphological and biochemical exploration of a syncretic process of cell death sharing apoptosis and necrosis. J Cell Physiol. 182:41-9.

[29] Geifman-Holtzman O, Grotegut CA, Gaughan JP. 2006. Diagnostic accuracy of noninvasive fetal $\mathrm{Rh}$ genotyping from maternal blood - a meta-analysis. Am J Obstet Gynecol. 2006 4:1163-73.

[30] Geifman-Holtzman O, Grotegut CA, Gaughan JP, Holtzman EJ, Floro C, Hernandez E. 2009. Non-invasive fetal RhCE genotyping from maternal blood. BJOG. 116(2):14451.

[31] Hahn S, Lapaire O, Tercanli S, Kolla V, Hösli I. Determination of fetal chromosome aberrations from fetal DNA in maternal blood: has the challenge finally been met? Expert Rev Mol Med. 2011 May 4;13:e16.

[32] Hahn S, Rusterholz C, Hösli I, Lapaire O. Cell-free nucleic acids as potential markers for preeclampsia. Placenta. 2011 Feb;32 Suppl:S17-20.

[33] Hughes RG, Craig JIO, Murphy WG, Greer IA. Causes and clinical consequences of Rhesus (D) haemolytic disease of the newborn: a study of Scottish population, 1985-1990. Br J Obstet Gynaecol 1994;101:297-300.

[34] Huppertz B, Kadyrov M, Kingdom JC. 2006. Apoptosis and its role in the trophoblast. Am J Obstet Gynecol. 195:29-39.

[35] Illanes S, Parra M, Serra R, Pino K, Figueroa-Diesel H, Romero C, Arraztoa JA, Michea L, Soothill PW. 2009. Increased free fetal DNA levels in early pregnancy plasma of women who subsequently develop preeclampsia and intrauterine growth restriction. Prenat Diagn. 29(12):1118-2.

[36] Illanes S, Soothill PW. 2006. Fetal therapy. In Progress in Obstetrics and Gynaecology. John Studd (Ed). Elselvier; United Kingdom: 65-78. 
[37] Illanes S, Soothill P. 2009. The non-invasive approach for the management of haemolytic disease of the fetus and newborn. Current aspects of the clinical management of haemolytic disease of the newborn and foetus. Expert Review of Hematology 5, 577-582.

[38] Legler TJ, Liu Z, Mavrou A, Finning KM, Hromadnikova I, Galbiati S, Meaney C, Hul; én MA, Crea F, Olsson ML, Maddocks DG, Huang D, Armstrong Fisher S, Sprenger-Haussels M, Soussan AA, van der Schoot CE. 2007. Workshop report on the extraction of foetal DNA from maternal plasma. Prenat Diagn. 27: 824-29.

[39] Legler, T.J., Lynen, R., Maas, J.H., Pindur, G., Kulenkampff, D., Suren, A., Osmers, R. \& Kohler, M. Prediction of fetal Rh D and Rh Cc Ee phenotype from maternal plasma with real-time polymerase chain reaction. Transfus Apher Sci, 2002. 27, 217-223.

[40] Li Y, Di Naro E, Vitucci A, Grill S, Zhong XY, Holzgreve W, Hahn S. Size fractionation of cell-free DNA in maternal plasma improves the detection of a paternally inherited beta-thalassemia point mutation by MALDI-TOF mass spectrometry. Fetal Diagn Ther. 2009;25(2):246-9. Epub 2009 Jun 5.

[41] Li Y, Finning K, Daniels G, Hahn S, Zhong X, Holzgreve W. 2008. Noninvasive genotyping fetal Kell blood group (KEL1) using cell-free fetal DNA in maternal plasma by MALDI-TOF mass spectrometry. Prenat Diagn. 28(3): 203-8.

[42] Liley AW Intrauterine transfusion of fetus in haemolytic disease. BMJ II 1963: 11071109.

[43] Lindenburg IT, Wolterbeek R, Oepkes D, Klumper FJ, Vandenbussche FP, van Kamp IL. Quality Control for Intravascular Intrauterine Transfusion Using Cumulative Sum (CUSUM) Analysis for the Monitoring of Individual Performance. Fetal Diagn Ther. 2011;29(4):307-14. Epub 2011 Feb 8.

[44] Lo YMD. Fetal RhD genotyping from maternal plasma: Ann Med 1999; 31:308-312

[45] Lo YM, Chan KC, Sun H, Chen EZ, Jiang P, Lun FM, Zheng YW, Leung TY, Lau TK, Cantor CR, Chiu RW. Maternal plasma DNA sequencing reveals the genome-wide genetic and mutational profile of the fetus. Sci Transl Med. 2010 Dec 8;2(61):61ra91.

[46] Lo YM, Corbetta N, Chamberlain PF, Rai V, Sargent IL, Redman CW, Wainscoat JS. 1997. Presence of fetal DNA in maternal plasma and serum. Lancet 350: 485-487.

[47] Lo YM, Tein MSC, Lau TK,Haines CJ, Leung TN, Poon PMK, Wainscoat JS, Johnson PJ, Chang AMZ, Hjelm NM. 1998. Quantitative analysis of fetal DNA in maternal plasma and serum: implications for noninvasive prenatal diagnosis. Am J Hum Genet. 62: 768-775.

[48] Mari G, Deter RL, Carpenter RL, et al. Noninvasive diagnosis by Doppler ultrasonography of fetal anemia due to maternal red-cell alloimmunization. N Engl J Med 2000;342:9-14.

[49] McGlone L, Simpson JH, Scott-Lang C, Cameron AD, Brennand J. 2009. Short term outcomes following intrauterine transfusion in Scotland. Arch Dis Child Fetal Neonatal. 23.

[50] Miura K, Higashijima A, Shimada T, Miura S, Yamasaki K, Abe S, Jo O, Kinoshita A, Yoshida A, Yoshimura S, Niikawa N, Yoshiura K, Masuzaki H. Clinical application of fetal sex determination using cell-free fetal DNA in pregnant carriers of X-linked genetic disorders. J Hum Genet. 2011 Apr;56(4):296-9. Epub 2011 Feb 10. 
[51] Müller SP, Bartels I, Stein W, Emons G, Gutensohn K, Köhler M, Legler TJ. 2008. The determination of the fetal $\mathrm{D}$ status from maternal plasma for decision making on Rh prophylaxis is feasible. Transfusion, 11: 2292-301.

[52] Murray JC, Karp LE, Williamson RA, Cheng EY, Luthy DA. Rh isoimmunization related to amniocentesis. Am J Med Genet 1983;16:527-34.

[53] Nanal R, Kyle P, Soothill PW. A classification of pregnancy losses after invasive prenatal diagnostic procedures: an approach to allow comparison of units with a different case mix. Prenat Diagn. 2003 Jun;23(6):488-92

[54] National Institute for Clinical Excellence: Technology Appraisal Guidance 156. 2008, review date: may 2011. Routine antenatal anti-D prophylaxis for women who are rhesus D negative. London, NICE.

[55] Nicolaides KH, Fontanarosa M, Gabbe SG, Rodeck CH. Failure of ultrasonographic parameters to predict the severity of fetal anemia in rhesus isoimmunization. Am J Obstet Gynecol 1988; 158: 920-6.

[56] Nicolaides KH, Soothill PW, Clewell WH, Rodeck CH, Mibashan RS, Campbell S. Fetal haemoglobin measurement in the assessment of red cell isoimmunisation. Lancet 1988; 1: 1073-75

[57] Nicolaides $\mathrm{KH}$, Soothill PW, Rodeck $\mathrm{CH}$, Clewell W Rh disease: intravascular fetal blood transfusion by cordocentesis. Fetal Ther. 1986; 1(4): 185-92.

[58] Nicolaides $\mathrm{KH}$, Warenski JC, Rodeck $\mathrm{CH}$. The relationship of fetal plasma protein concentration and Hemoglobin level to the development of hydrops in rhesus isoimmunization. Am J Obstet Gynecol 1985; 152: 341-4

[59] Oepkes D, Seaward PG, Vandenbussche FP, Windrim R, Kingdom J, Beyene J, Kanhai $\mathrm{HH}$, Ohlsson A, Ryan G; DIAMOND Study Group.Doppler ultrasonography versus amniocentesis to predict fetal anemia.N Engl J Med. 2006 Jul 13;355(2):15664.

[60] Queenan JT. Current management of the Rh-sensitized patient. Clin Obstet Gynecol 1982; 25: 293-301

[61] Rodeck CH, Kemp JR, Holman CA, Whitmore CA, Karnicki J,Austin MA. Direct intravascular fetal blood transfusion by fetoscopy in severe Rhesus isoimmunisation. Lancet I 1981:625- 627.

[62] Rouillac-Le Sciellour, C., Puillandre, P., Gillot, R., Baulard, C., Metral, S., Le Van Kim, C., Cartron, J.P., Colin, Y. \& Brossard, Y. Large-scale pre-diagnosis study of fetal RHD genotyping by PCR on plasma DNA from RhD-negative pregnant women. Mol Diagn, 2004. 8, 23-31.

[63] Scheffer P, van der Schoot C, Page-Christiaens G, de Haas M. Noninvasive fetal blood group genotyping of rhesus $\mathrm{D}, \mathrm{c}, \mathrm{E}$ and of $\mathrm{K}$ in alloimmunised pregnant women: evaluation of a 7-year clinical experience. BJOG. 2011 Jun 14.

[64] Sehnert AJ, Rhees B, Comstock D, de Feo E, Heilek G, Burke J, Rava RP. Optimal detection of fetal chromosomal abnormalities by massively parallel DNA sequencing of cell-free fetal DNA from maternal blood. Clin Chem. 2011 Jul;57(7):1042-9. Epub 2011 Apr 25.

[65] Socol ML, MacGregor SN, Pielet BW, Tamura RK, Sabbagha RE. Percutaneous umbilical transfusion in severe rhesus isoimmunization: Resolution of fetal hydrops. Am J Obstet Gynecol 1987; 157: 1369-75 
[66] Soothill PW, Nicolaides $\mathrm{KH}$, Rodeck $\mathrm{CH}$, Clewell WH, Lindridge J. Relationship of fetal hemoglobin and oxygen content to lactate concentration in $\mathrm{Rh}$ isoimmunized pregnancies. Obstet Gynecol 1987; 69: 268-71

[67] Szczepura A, Osipenko L, Freeman K. A new fetal RHD genotyping test: costs and benefits of mass testing to target antenatal anti-D prophylaxis in England and Wales. BMC Pregnancy Childbirth. 2011 Jan 18;11:5.

[68] Tabor A, Bang J, Nørgaard-Pedersen B: Feto-maternal haemorrhage associated with genetic amniocentesis: results of a randomized trial. Br J Obstet Gynecol 1987; 94:528-34

[69] Thein AT, Soothill P. Antenatal invasive therapy. Eur J Pediatr. 1998 Jan; 157 Suppl 1: S2-6

[70] Tounta G, Vrettou C, Kolialexi A, Papantoniou N, Destouni A, Tsangaris GT, Antsaklis A, Kanavakis E, Mavrou A. A multiplex PCR for non-invasive fetal RHD genotyping using cell-free fetal DNA. In Vivo. 2011 May-Jun;25(3):411-7.

[71] Tsui NB, Kadir RA, Chan KC, Chi C, Mellars G, Tuddenham EG, Leung TY, Lau TK, Chiu RW, Lo YM. Noninvasive prenatal diagnosis of hemophilia by microfluidics digital PCR analysis of maternal plasma DNA. Blood. 2011 Mar 31;117(13):3684-91. Epub 2011 Jan 24.

[72] Tynan JA, Mahboubi P, Cagasan LL, van den Boom D, Ehrich M, Oeth P. Restriction enzyme-mediated enhanced detection of circulating cell-free fetal DNA in maternal plasma. J Mol Diagn. 2011 Jul;13(4):382-9. Epub 2011 May 6.

[73] Ubarniak S, 2002. The clinical application of anti-D prophilaxis. In: Alloimmune Disorders of Pregnancy: Anaemia,Thrombocytopenia and Neutropenia in the Fetus and Newborn. Andrew Hadley, Peter Soothill (Ed). Cambridge University Press; Cambridge: 97-121.

[74] Van der Schoot, C.E., Soussan, A.A., Koelewijn, J., Bonsel, G., Paget-Christiaens, L.G. \& de Haas, M. Non-invasive antenatal RHD typing. Transfus Clin Biol. 2006.13, 53-57.

[75] Van der Schoot, C.E., Tax, G.H., Rijnders, R.J., de Haas, M. \& Christiaens, G.C. 2003. Prenatal typing of $\mathrm{Rh}$ and Kell blood group system antigens: the edge of a watershed. Transfus Med Rev. 17: 31-44.

[76] Van Kamp IL, Klumper FJCM, Bakkum RSLA, et al. The severity of immune fetal hydrops is predictive for fetal outcome after intrauterine treatment. Am J Obstet Gynecol 2001;185:668-673.

[77] Vyas S, Nicolaides KH, Campbell S. Doppler examination of the middle cerebral artery in anemic fetuses. Am J Obstet Gynecol 1990; 162: 1066-8

[78] Wataganara T, Bianchi DW. 2004. Fetal cell-free nucleic acids in the maternal circulation: new clinical applications. Ann N Y Acad Sci . 1022: 90-99.

[79] Weiner CP, Wenstrom KD, Sipes SL, Williamson RA. Risk factors for cordocentesis and fetal intravascular transfusion. Am J Obstet Gynecol. 1991 Oct; 165 (4 Pt 1): 1020-5.

[80] Zipursky A, Paul VK The global burden of Rh disease, Arch Dis Child Fetal Neonatal Ed. 2011 Mar;96(2):F84-5. Epub 2010 Oct 30. 


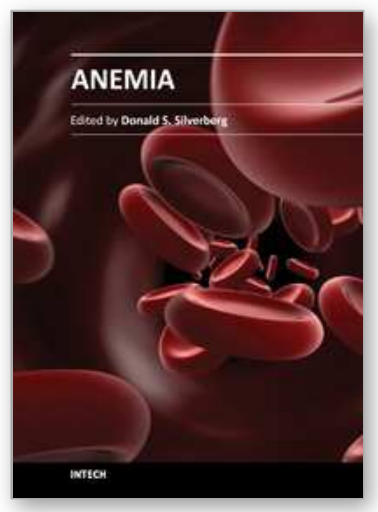

\author{
Anemia \\ Edited by Dr. Donald Silverberg
}

ISBN 978-953-51-0138-3

Hard cover, 440 pages

Publisher InTech

Published online 29, February, 2012

Published in print edition February, 2012

This book provides an up- to- date summary of many advances in our understanding of anemia, including its causes and pathogenesis, methods of diagnosis, and the morbidity and mortality associated with it. Special attention is paid to the anemia of chronic disease. Nutritional causes of anemia, especially in developing countries, are discussed. Also presented are anemias related to pregnancy, the fetus and the newborn infant. Two common infections that cause anemia in developing countries, malaria and trypanosomiasis are discussed. The genetic diseases sickle cell disease and thalassemia are reviewed as are Paroxysmal Nocturnal Hemoglobinuria, Fanconi anemia and some anemias caused by toxins. Thus this book provides a wide coverage of anemia which should be useful to those involved in many fields of anemia from basic researchers to epidemiologists to clinical practitioners.

\title{
How to reference
}

In order to correctly reference this scholarly work, feel free to copy and paste the following:

Sebastian Illanes and Rafael Jensen (2012). Clinical Management of Hemolytic Disease of the Newborn and Fetus, Anemia, Dr. Donald Silverberg (Ed.), ISBN: 978-953-51-0138-3, InTech, Available from: http://www.intechopen.com/books/anemia/clinical-management-of-hemolytic-disease-of-the-newborn-andfetus

\section{INTECH}

open science | open minds

\author{
InTech Europe \\ University Campus STeP Ri \\ Slavka Krautzeka 83/A \\ 51000 Rijeka, Croatia \\ Phone: +385 (51) 770447 \\ Fax: +385 (51) 686166 \\ www.intechopen.com
}

\author{
InTech China \\ Unit 405, Office Block, Hotel Equatorial Shanghai \\ No.65, Yan An Road (West), Shanghai, 200040, China \\ 中国上海市延安西路65号上海国际贵都大饭店办公楼405单元 \\ Phone: +86-21-62489820 \\ Fax: $+86-21-62489821$
}


(C) 2012 The Author(s). Licensee IntechOpen. This is an open access article distributed under the terms of the Creative Commons Attribution 3.0 License, which permits unrestricted use, distribution, and reproduction in any medium, provided the original work is properly cited. 